\title{
Service Quality Ditinjau Dari Kepemimpinan Transformasional Pimpinan Yayasan Terhadap Guru Pesantren
}

\author{
Tria Sari, Winida Marpaung, Diny Atrizka \\ Universitas Prima Indonesia \\ Email: triabapao@gmail.com
}

\begin{abstract}
This study aims to determine the relationship between transformational leadership and service quality. The hypothesis proposed in this study is that there is a positive relationship between transformational leadership and service quality, assuming the higher the transformational leadership, the higher the service quality and vice versa. The research subjects used in this study were Darul Arafah Islamic Boarding School teachers in Lau Bakeri Deli Serdang, as many as 100 people. Data collection techniques using purposive sampling. The research data were obtained using transformational leadership scale and service quality. Analysis of the data used is to use product moment correlation through SPSS 17 for windows. The results of data analysis showed a correlation coefficient of $\mathrm{r}=$ 0.532 and a significance value of 0.000 ( $\mathrm{p}<0.05$ ). Based on the results of this study it can be concluded that the research hypothesis is accepted, namely there is a positive relationship between transformational leadership and service quality.
\end{abstract}

Keywords : Transformational Leadership, Service Quality

\begin{abstract}
Abstrak
Penelitian ini bertujuan untuk mengetahui hubungan antara kepemimpinan transformasional dengan service quality. Hipotesis yang diajukan dalam penelitian ini adalah ada hubungan positif antara kepemimpinan transformasional dengan service quality, dengan asumsi semakin tinggi kepemimpinan transformasional, maka semakin tinggi service quality dan sebaliknya. Subjek penelitian yang digunakan dalam penelitian ini adalah guru Pesantren Darul Arafah di Lau Bakeri Deli Serdang, sebanyak 100 orang. Teknik pengambilan data dengan menggunakan purposive sampling. Data penelitian diperoleh dengan menggunakan skala kepemimpinan transformasional dan service quality. Analisis data yang digunakan adalah menggunakan korelasi product moment melalui bantuan SPSS 17 for windows. Hasil analisis data menunjukkan koefisien korelasi sebesar $r=0,532$ dan nilai signifikansi sebesar 0.000 ( $\mathrm{p}<0.05$ ). Berdasarkan hasil penelitian ini dapat ditarik kesimpulan bahwa hipotesis penelitian diterima, yaitu ada hubungan positif antara kepemimpinan transformasional dengan service quality.
\end{abstract}

Kata kunci : Kepemimpinan Transformasional, Kualitas Pelayanan

\section{Pendahuluan}

Sejak seorang manusia dilahirkan di dunia ini, manusia tersebut akan terus mengalami proses pembelajaran hingga akhir hayatnya. Proses pembelajaran tersebut dapat diperoleh dari mana saja, salah satunya melalui jalur pendidikan. Menurut Good (dalam Notoatmodjo, 2003), pendidikan adalah proses sosial di mana lingkungan yang terorganisir mampu mempengaruhi seseorang untuk mengembangkan kecakapan sikap dan perilaku dalam diri sendiri dan bermasyarakat. Oleh karena itu, pendidikan menjadi hal yang krusial dikarenakan pendidikan berhubungan langsung dalam pembentukan perkembangan manusia agar dapat mengaktualisasian diri secara optimal melalui aktivitas dalam proses pembelajaran yang dapat mengasah atau menambah kemampuan (skill) individu.

Pada zaman sekarang telah terdapat berbagai lembaga pendidikan, mulai dari lembaga pendidikan khusus anak usia dini hingga jenjang perguruan tinggi. Lembaga pendidikan yang memberikan kemampuan ( $s k i l l$ ) serta pengetahuan dasar adalah lembaga pendidikan sekolah, baik SD, SMP, hingga SMA dan sederajat.

Selain itu di Indonesia juga terdapat sekolah yang secara khusus membina akhlak dan memperdalam ilmu keagamaan para siswanya, seperti pendidikan di pondok pesantren. 
Menurut Arifin (1995), pondok pesantren merupakan suatu lembaga pendidikan agama Islam yang tumbuh serta diakui oleh masyarakat sekitar, dengan sistem asrama di mana menerima pendidikan agama melalui sistem pengajian atau madrasah yang sepenuhnya berada di bawah kedaulatan dari kepemimpinan seorang atau beberapa orang kiai dengan ciri-ciri khas yang bersifat kharismatik serta independen dalam segala hal. Berdasarkan pengertian yang telah dipaparkan, dapat diketahui bahwa sejatinya pesantren merupakan suatu instansi pendidikan keagamaan yang tidak berbeda dari sekolah.

Menurut Peraturan Pemerintah (PP) Nomor 19 Tahun 2005 tentang Standar Nasional Pendidikan, semua sekolah di Indonesia diarahkan dapat menyelenggarakan pendidikan yang memenuhi standar nasional. Berdasarkan hal tersebut, dapat diketahui bahwa pihak sekolah beserta jajarannya harus melaksanakan tugas tanggung jawabnya demi tercapai seluruh penetapan standar akreditas tersebut. Pernyataan di atas sesuai dengan pendapat yang dipaparkan oleh Wibowo (2013) yang menyatakan bahwa, sumber daya manusia merupakan faktor penentu internal bagi keberhasilan suatu instansi.

Pada suatu instansi seperti sekolah, performa guru sebagai penggerak operasional sangat penting demi kemajuan sekolah. Melalui performa baik yang ditampilkan, maka efektivitas instansi dapat tercapai dan tercipta citra yang baik (Mondy, 2009). Permasalahan yang sering terjadi pada guru-guru yang dinilai tidak memberikan kinerja yang baik adalah seperti kurang berkompeten dalam menyampaikan materi, tidak disiplin, tidak menguasai materi yang akan diajarkan, dan tidak mampu memahami cara pendekatan yang baik terhadap para siswanya serta terkesan tidak peduli. Berbagai permasalahan di atas menunjukkan bahwa para guru tidak memberikan service quality yang baik terhadap siswa.

Menurut Tjiptono (2005), service quality adalah suatu tingkat keunggulan yang diharapkan dimana pengendalian atas tingkat keunggulan tersebut bertujuan untuk memenuhi kebutuhan pelanggan. Parasuraman (2001) menyatakan bahwa konsep service quality adalah suatu pengertian yang kompleks tentang mutu yang memuaskan atau tidak memuaskan. Konsep service quality dikatakan bermutu, apabila pelayanan yang diharapkan lebih kecil daripada pelayanan yang dirasakan (bermutu). Artinya, service quality bukanlah dilihat dari sudut pandang pihak penyelenggara atau penyedia layanan, melainkan berdasarkan persepsi pelanggan, karena pelangganlah yang mengkonsumsi dan merasakan pelayanan yang diberikan sehingga merekalah yang seharusnya menilai dan menentukan service quality. Dikatakan konsep service quality memenuhi harapan apabila pelayanan yang diharapkan sama dengan yang dirasakan (memuaskan). Demikian pula dikatakan persepsi tidak memenuhi harapan apabila pelayanan yang diharapkan lebih besar dari pada pelayanan yang dirasakan (tidak bermutu).

Salah satu faktor yang mempengaruhi service quality adalah kepemimpinan transformasional. 'Penelitian yang dilakukan oleh Putra (2016) pada 35 perusahaan perbankan di Surabaya mengungkap bahwa kepemimpinan transformasional memberikan pengaruh yang positif dan signifikan terhadap service quality. Artinya, pemimpin mampu memberikan pengaruh kepada karyawannya dengan kecakapan yang dimiliki, mampu menanamkan visi-misinya terhadap seluruh karyawannya, dan memberikan kesempatan serta kepercayaan pada karyawan-karyawannya dapat meningkatkan service quality para karyawannya. Ini menunjukkan bahwa semakin baik kepemimpinan transformasional maka semakin baik pula service quality. Sebaliknya semakin buruk kepemimpinan transformasional, maka semakin buruk pula service quality.

Dasar teori kepemimpinan transformasional adalah para pemimpin organisasi harus mampu menghadapi perubahan-perubahan secara berkesinambungan. Sementara itu, Burns (dalam Northouse, 2007) menyatakan bahwa kepemimpinan transformasional merupakan sebuah proses saling menguatkan diantara para pemimpin dan pengikut ke tingkat moralitas dan motivasi yang lebih tinggi.

Sejalan dengan teori sebelumnya, Bass (dalam Ancok, 2012) menyatakan bahwa gaya kepemimpinan transformasional yaitu suatu kepemimpinan yang mampu mendorong anggotanya untuk mengembangkan aspirasi dan memperoleh makna dalam bekerja, mampu mengembangkan pemimpin-pemimpin baru di lingkungan kerjanya, menciptakan lingkungan 
kerja yang apresiatif, dan menjadikan dirinya sebagai model integritas bagi anggotanya. Berdasarkan pengertian tersebut, diketahui bahwa kepemimpinan transformasional memotivasi para pengikutnya untuk meningkatkan tingkat kesadaran tentang arti penting dan nilai tujuan yang ditentukan dan diiinginkan, meminta para pengikut untuk mengutamakan kepentingan tim atau organisasi di atas kepentingan pribadi dan menggerakkan pengikut untuk menuju kebutuhan pada level yang lebih tinggi.

Adanya kepemimpinan transformasional diharapkan mampu mengubah (to transform) persepsi, sikap, dan perilaku bawahan terlepas dari meningkat-tidaknya perubahan yang terjadi. Secara konseptual, kepemimpinan transformasional adalah kemampuan pemimpin dalam mengubah lingkungan kerja, motivasi kerja, pola kerja, dan nilai-nilai kerja bawahan sehingga bawahan akan lebih mengoptimalkan kinerja untuk mencapai tujuan organisasi (Wutun, 2001).

Penelitian yang dilakukan Ismail (2009) semakin mempertegas bahwa kepemimpinan transformasional merupakan salah satu faktor yang mempengaruhi service quality. Diketahui bahwa ada dua dimensi dari kepemimpinan transformasional yang memiliki pengaruh yang positif dan signifikan terhadap service quality, yakni intellectual stimulation dan individual consideration. Ini menunjukkan bahwa service quality karyawan dapat ditingkatkan melalui adanya seorang pemimpin yang mampu mempengaruhi karyawannya melalui pengetahuan dan kemampuannya dalam konteks pekerjaan serta tahu persis pelatihan apa yang harus diberikan kepada para pengikutnya. Artinya, semakin baik kepemimpinan transformasional maka semakin baik pula service quality. Sebaliknya, semakin buruk kepemimpinan transformasional maka semakin buruk pula service quality.

Berdasarkan berbagai pemaparan di atas, penulis tertarik untuk melakukan suatu penelitian yang berjudul, "Service quality ditinjau dari Gaya Kepemimpinan Transformasional Pimpinan Yayasan Terhadap Guru di Pesantren Darul Arafah Di Lau Bakeri, Deli Serdang" yang bertujuan untuk mengetahui hubungan antara kepemimpinan transformasional dengan service quality.

\section{Metode Penelitian}

\subsection{Populasi dan Sampel}

Populasi dalam penelitian ini adalah seluruh guru Pesantren Darul Arafah sebanyak 140 orang. Untuk menentukan jumlah sampel digunakan tabel Isaac dan Michael dengan taraf signifikansi $5 \%$ dengan populasi guru sebanyak 140 orang menjadi 100 orang.

2.2 Teknik Sampling

Metode pengambilan sampel yang digunakan adalah Purposive Sampling. Adapun kriteria dalam penelitian ini adalah guru non abdi di bawah kepemimpinan Kepala Yayasan Pesantren Darul Arafah. Guru non abdi adalah guru yang sudah memiliki gelar S1 dan memiliki masa kerja minimal 1 tahun.

\subsection{Metode Pengumpulan data}

Metode penelitian yang digunakan untuk mendapatkan data yang diperlukan dalam penelitian ini adalah metode skala (dalam Azwar, 2006). Adapun jenis skala yang digunakan dalam penelitian ini adalah skala Likert. Skala yang digunakan dalam penelitian ini terdiri dari dua skala, yaitu skala service quality dan skala kepemimpinan transformasional. Skala service quality disusun berdasarkan dimensi-dimensi service quality yang dipaparkan oleh Akbaba (2006), antara lain tangible, adequacy in service supply, understanding and caring, assurance, dan convenience.

Skala kepemimpinan transformasional yang digunakan dalam penelitian ini disusun berdasarkan karakteristik kepemimpinan transformasional yang dikemukakan oleh Ancok (2012) antara lain pengaruh yang diidealkan (idealized influenced), stimulasi intelektual (intellectual stimulation), kepedulian secara perorangan (individual consideration), dan motivasi yang inspirasional (inspirasional motivation).

2.4 Metode Analisis Data 
Metode analisis data menggunakan korelasi Product Moment (Pearson Correlation) dengan bantuan SPSS 17 for windows untuk mengetahui bagaimana hubungan antara variabel kepemimpinan transformasional dan service quality.

\section{Hasil Penelitian dan Pembahasan}

\subsection{Hasil Analisis Data}

Sebelum data-data yang terkumpul dianalisis lebih jauh menggunakan teknik Product Moment (Pearson Correlation), terlebih dahulu dilakukan uji asumsi untuk mengetahui normalitas sebaran dan linieritas hubungannya. Berdasarkan hasil uji normalitas dan linieritas, diketahui bahwa data penelitian telah memenuhi syarat uji asumsi untuk dapat dilakukan analisis Product Moment (Pearson Correlation). Hasil uji normalitas sebaran dan uji linieritas hubungan dapat dilihat pada Tabel 1 dan Tabel 2 yaitu sebagai berikut.

Tabel 1.Hasil Uji Normalitas

\begin{tabular}{cccc}
\hline Variabel & Nilai & KS-Z & Ket. \\
\hline SQ & $0,146^{*}$ & 0,980 & Normal \\
KT & $0,3045^{*}$ & 0,761 & Normal \\
\hline
\end{tabular}

Note. SQ = Service Quality; KT = Kepemimpinan Transformasional $* \mathrm{p}<0,05$

Berdasarkan tabel 1, uji normalitas yang dilakukan terhadap variabel service quality koefisien $\mathrm{KS}-\mathrm{Z}=0,980$ dengan sig sebesar 0,292 untuk uji 2 (dua) arah, sedangkan penelitian ini memiliki hipotesis satu arah, sehingga yang dipakai adalah uji 1 (satu) ekor/ sig 1-tailed sebesar 0,146 ( $p>0,05$ ), yang berarti bahwa data pada variabel service quality memiliki sebaran atau berdistribusi normal. Sedangkan Uji normalitas pada variabel kepemimpinan transformasional diperoleh koefisien KS-Z = 0,761 dengan Sig sebesar 0,609 untuk uji 2 (dua) arah dan sig sebesar 0,3045 untuk uji 1 (satu) arah ( $\mathrm{p}>0,05$ ), yang berarti bahwa data pada variabel kepemimpinan transformasional memiliki sebaran atau berdistribusi normal

Tabel 2.Hasil Uji Linieritas Hubungan

\begin{tabular}{cccc}
\hline Variabel & F & Sig. & Ket. \\
\hline SQ & 50,460 & 0,000 & Linear \\
KT & & & \\
\hline
\end{tabular}

Note. SQ = Service Quality; KT = Kepemimpinan Transformasional

Berdasarkan tabel 2 dapat dikatakan bahwa variabel service quality dan kepemimpinan transformasional memiliki hubungan linear. Hal ini terlihat dari nilai signifikansi yang diperoleh yaitu 0,000 maka $\mathrm{p}<0,05$, dapat disimpulkan bahwa kedua variabel memiliki hubungan linear dan telah memenuhi syarat untuk dilakukan analisa korelasi Product Moment. Hipotesis dalam penelitian ini adalah ada hubungan yang positif antara kepemimpinan transformasional dengan service quality pada guru Pesantren Darul Arafah di Lau Bakeri, Deli Serdang. Hasil uji hipotesis dapat dilihat pada Tabel 3 yaitu sebagai berikut.

Tabel 3. Korelasi Antara Kepemimpinan Transformasional dengan Service Quality

\begin{tabular}{ccc}
\hline Variabel & $\begin{array}{c}\text { Pearson } \\
\text { Correlation }\end{array}$ & Signifikansi \\
\hline SQ & 0,532 & 0,000 \\
KT & & \\
\hline
\end{tabular}

Note. SQ = Service Quality; KT = Kepemimpinan Transformasional

Berdasarkan hasil analisis korelasi antara kepemimpinan transformasional dengan service quality, diperoleh koefisien korelasi Product Moment sebesar 0,532 dengan nilai p sebesar 0,000 ( $\mathrm{p}<0.05$, Sig. 1 tailed). Hasil tersebut menunjukkan adanya korelasi positif antara kepemimpinan transformasional dengan service quality. 
Tria Sari, Winida Marpaung, Diny Atrizka

Psyche 165 Journal Vol 13 No 1 (2020) 132-139

Tabel 4. Model Summary Sumbangan Efektif

\begin{tabular}{ccccc}
\hline Model & R & R2 & $\begin{array}{c}\text { Adjusted } \\
\text { R2 }\end{array}$ & $\begin{array}{c}\text { Std. Error of } \\
\text { the Estimate }\end{array}$ \\
\hline 1 & 0,532 & 0,283 & 0,276 & $\begin{array}{c}6,95 \\
6\end{array}$ \\
\hline
\end{tabular}

Berdasarkan tabel 4 di atas, dapat disimpulkan dalam penelitian ini diperoleh koefisien determinasi $R$ Square $\left(\mathrm{R}^{2}\right)$ sebesar 0,283. Berdasarkan hasil tersebut, dapat disimpulkan bahwa sumbangan $28,3 \%$ persen kepemimpinan transformasional mempengaruhi service quality selebihnya $71,7 \%$ persen dipengaruhi oleh faktor lain, seperti kepuasan kerja, employee empowermesnt, motivasi kerja, Organizational Citizenship Behavior (OCB), disiplin kerja, brand image, pelatihan keterampilan service quality, kompensasi dan gaya kepemimpinan dan remunerasi.

Berdasarkan hasil penelitian di atas, diketahui bahwa semakin baik kepemimpinan transformasional, maka semakin menurun service quality. Sebaliknya semakin buruk kepemimpinan transformasional, maka semakin tinggi service quality.

\section{Pembahasan}

Hasil penelitian pada 100 guru Pesantren Darul Arafah yang menjadi subjek penelitian, diperoleh hasil bahwa ada hubungan antara kepemimpinan transformasional dengan service quality dengan koefisien korelasi Product Moment sebesar $\mathrm{r}=0,532$ dan nilai $\mathrm{p}=0.000$, artinya semakin tinggi kepemimpinan transformasional maka semakin tinggi service quality, dan sebaliknya semakin rendah kepemimpinan transformasional maka semakin rendah service quality.

Hasil penelitian yang menyatakan adanya hubungan antara kepemimpinan transformasional dengan service quality sejalan dengan pendapat Northouse (2013) yang menyatakan bahwa kepemimpinan transformasional murni secara positif memengaruhi identitas moral dan emosi pengikut. Selain itu, kepemimpinan transformasional murni juga secara positif terkait dengan suasana etis, pengambilan keputusan dan tindakan moral kelompok. Jika dihubungkan dengan pengertian service quality menurut Sheldon (dalam Meyer \& Allen, 1997), service quality sebagai suatu attitude atau orientasi terhadap organisasi yang berhubungan dengan identitas seseorang terhadap organisasi, maka dapat diketahui secara implisit bahwa kepemimpinan transformasional mempengrauhi identitas seseorang terhadap organisasinya agar mau tetap tinggal dan mendedikasikan dirinya terhadap organisasi tersebut.

Adapun hasil penelitian ini berbanding lurus dengan penelitian yang dilakukan oleh $\mathrm{He}$ (2016) juga menyatakan bahwa ada hubungan antara kepemimpinan transformasional dan service quality. Hal ini terungkap melalui penelitiannya kepada 250 karyawan fronliner, diketahui bahwa kepemimpinan transformasional memiliki pengaruh positif dan signifikan terhadap service quality dengan $r=0.279$ dengan $\mathrm{p}<0,001$. Artinya, semakin baik kepemimpinan transformasional maka semakin tinggi pula service quality yang dirasakan nasabah.

Penelitian ini menunjukkan bahwa tidak ada guru Pesantren Darul Arafah memiliki service quality yang masuk dalam kategori rendah, sedangkan service quality pada guru yang termasuk kategori sedang berjumlah 40 orang dengan persentase 40 persen, dan service quality pada guru yang dikategorikan tinggi berjumlah 60 guru dengan persentase 60 persen. Berdasarkan pemaparan diatas dapat disimpulkan bahwa rata-rata guru Pesantren Darul Arafah memiliki tingkat service quality yang tinggi.

Berdasarkan hasil observasi dan wawancara terhadap guru yang memiliki persentase 40 persen menunjukkan service quality sedang, dapat diungkapkan melalui faktor Convenience. Para guru yang bekerja di Pesantren Darul Arafah menyatakan bahwa mereka berusaha sebaik mungkin dalam memberikan layanan mereka terhadap para santri. Para guru sadar bahwa mereka perlu menegur para santri yang melakukan tindakan yang berbahaya. Namun, tugas dan pekerjaan 
yang padat membuat mereka terkadang enggan untuk menegur para santri. Selain itu, sebagian guru juga diketahui peduli dengan perkembangan para santri tetapi ada pula guru yang hanya sekedar menyampaikan materi pembelajarannya. Hasil wawancara terhadap para guru mengungkap bahwa guru telah merassa memberikan layanan terbaik mereka kepada para santri. Selanjutnya, guru dengan kategori service quality sedang juga dapat terlihat dari faktor understanding and caring. Hasil observasi dan wawancara mengungkapkan bahwa para guru menyatakan diri mereka dibiasakan untuk memberikan pelayanan yang ramah dan memerhatikan setiap santri. Namun berdasarkan wawancara terhadap para santri, diketahui pula bahwa ada beberapa guru yang tidak terlalu mempedulikan para santri. Diketahui para guru hanya sekedar mengajar serta membimbing para santri pada waktu belajar ataupun waktu-waktu tertentu saja. Saat ditanyakan pada guru-guru pesantren, alasan banyaknya pekerjaan menjadi kendala mereka untuk lebih memerhatikan para santri. Walaupun begitu, para guru menyatakan bahwa mereka telah melakukan tugas tanggung jawab mereka dengan benar.

Sisa guru Pesantren Darul Arafah menunjukkan service quality yang tinggi dengan persentase 60 persen terlihat dari faktor Adequacy in Service Supply. Berdasarkan hasil observasi dan wawancara terhadap para santri, diketahui bahwa semua guru di Pesantren Darul Arafah mampu melakukan pengajaran yang baik. Para guru dianggap mampu memberikan jawaban yang tepat atas segala pertanyaan yang ditanyakan oleh para santri, kapan pun ketika para santri bertanya. Para santri menyatakan bahwa para guru juga merupakan orang-orang yang konsisten terhadap ucapannya. Menurut penuturan para guru, para santri merupakan tanggung jawab mereka. Mereka berusaha semaksimal mungkin untuk memperlakukan para santri sebagai anakanak mereka. Beberapa guru menyatakan bahwa para santri yang ada di pesantren merupakan orang-orang yang perlu dibentuk akhlaknya sehingga harus selalu diperhatikan. Untuk itu, para guru selalu berusaha untuk memenuhi tugas tanggung jawabnya secara konsisten, baik dalam kegiatan belajar-mengajar ataupun di luar waktu belajar.

Selain itu, kategori service quality yang tinggi juga terlihat dari faktor assurance. Hasil ini diketahui dari banyak guru yang menyatakan bahwa mereka mengerahkan seluruh tenaga dan pikiran mereka untuk menciptakan suasana belajar yang aman dan menyenangkan bagi para santri. Hal tersebut bukan hanya sekedar dengan cara-cara yang dapat terlihat, seperti desain ruangan. Namun para guru menyatakan membangun kepercayaan satu sama lain antara guru dan santri sangatlah penting. Saat para siswa telah mempercayai para guru, tidak hanya kegiatan belajar yang menjadi lebih mudah, tetapi juga mereka merasa lebih aman. Para santri turut menyatakan bahwa pengetahuan yang mereka dapatkan membuat mereka siap menghadapi kehidupan yang sebenarnya kelak ketika tamat sekolah. Mereka percaya akan pengetahuan yang telah mereka dapatkan berguna di kemudian hari.

Melalui penelitian ini, juga diperoleh data bahwa tidak ada guru yang menilai kepemimpinan transformasional atasannya rendah, 46 guru menilai bahwa kepemimpinan transformasional atasannya dalam kategori sedang dengan persentase sebesar 46 persen dan guru yang menilai atasannya dengan kategori kepemimpinan transformasional yang tinggi berjumlah 54 guru dengan persentase 54 persen. Berdasarkan penjelasan diatas dapat disimpulkan rata-rata guru Pesantren Darul Arafah menilai atasannya memiliki kepemimpinan transformasional yang tinggi.

Berdasarkan hasil observasi dan wawancara terhadap guru menilai atasan mereka yang memiliki persentase 46 persen menunjukkan kepemimpinan transformasional sedang, dapat diungkapkan melalui karakteristik stimulasi intelektual. Banyak guru yang menyatakan bahwa kepala yayasan merupakan seseorang yang sangat berperan besar dalam kinerja para guru. Pribadi yang rasional dan selalu memberikan jalan keluar yang bijak pada setiap permasalahan yang muncul. Selain itu, para guru juga menyatakan bahwa kepala yayasan adalah orang yang sangat senang berbagi ilmu yang bermanfaat dan dapat diimplementasikan dalam pekerjaan mereka sebagai guru pesantren. Pengalaman yang dibagikan oleh kepala yayasan merupakan sesuatu yang disukai sebagian besar guru di Pesantren Darul Arafah. Namun ada juga guru yang menyatakan bahwa pemikiran dari kepala yayasan terkadang terlalu idealis dan kurang dapat dengan hati nurani. Sebagian guru menganggap konsep yang dibagikan oleh kepala yayasan 
terkesan terlalu sainstifik. Para guru tersebut menganggap hal tersebut tentunya sulit diimplementasikan pada instansi pendidikan keagamaan.

Selain itu, kategori kepemimpinan transformasional yang sedang juga tampak melalui karakteristik pertimbangan yang bersifat individual. Berdasarkan hasil observasi dan wawancara terhadap guru-guru Pesantren Darul Arafah diketahui bahwa pemimpin mereka merupakan pribadi yang hangat dan merupakan orang yang dapat dipercaya untuk diajak bicara secara personal. Para guru sangat senang apabila mendapatkan kesempatan untuk berbicara kepada kepala yayasan. Namun, kesibukan kepala yayasan sering membuat beliau tidak memiliki waktu banyak untuk berbicara kepada para guru, sehingga beliau terkadang hanya memberikan perhatian secara umum kepada seluruh guru.

Sisa guru Pesantren Darul Arafah menilai kepemimpinan transformasional atasannya termasuk kategori tinggi dengan persentase 54 persen terlihat dari karakteristik pengaruh yang ideal. Hasil observasi dan wawancara yang dilakukan peneliti mengungkapkan bahwa para guru merasa kepala yayasan mereka adalah orang yang disegani. Terbukti dari beberapa guru yang mengatakan bahwa mereka selalu menuruti arahan yang diberikan kepala yayasan. Kepala yayasan merupakan sosok yang ideal untuk diteladani oleh sebagian guru. Para guru menyatakan bahwa jika kepala yayasan mengambil pensiun atau tidak bekerja lagi, hal tersebut akan mempengaruhi mereka karena kehilangan seorang sosok pemimpin yang berkharisma. Para guru menyatakan bahwa mereka selalu seolah-olah merasa semangat bila sedang kepala yayasan, seperti ada kekuatan tersendiri yang memotivasi mereka.

Kepemimpinan transformasional dalam kategori tinggi juga terlihat dari karakteristik motivasi yang inspirasional. Menurut para guru, kepala yayasan adalah orang yang dapat dijadikan role model karena memiliki semangat dan passion yang begitu besar dalam mengajar. Tindakan kepala yayasan yang memberikan kesempatan kepada setiap guru untuk mencoba dan berkembang, serta adanya sifat ingin menampung setiap pendapat setiap guru semakin membuat para guru merasa dihargai dan kagum dengan sosok kepala yayasan. Selanjutnya, ada juga guru yang menyatakan bahwa teknik mengajar kepala yayasan sangatlah terorganisir dan jelas. Kemampuan mengajar kepala yayasan ini yang selalu dijadikan panutan bagi guru tersebut dalam melaksanakan pekerjaan sehari-hari.

Berdasarkan penjelasan diatas maka dapat dikatakan bahwa seoranng pemimpin yang dapat menginspirasi, mengarahkan anggotanya, memiliki kepribadian yang hangat dan terbuka kepada anggotanya dapat meningkatkan service quality anggotanya terhadap suatu organisasi, baik dari segi aspek organisasi itu sendiri, ataupun lingkungan kerja, sehingga dapat disimpulkan bahwa ada hubungan positif antara kepemimpinan transformasional dengan service quality. Artinya semakin tinggi kepemimpinan transformasional yang dirasakan para guru, maka semakin tinggi service quality, dan sebaliknya semakin rendah kepemimpinan transformasional maka semakin rendah service quality.

\section{Kesimpulan}

Adapun kesimpulan dari penelitian ini adalah Ada hubungan positif antara kepemimpinan transformasional dengan service quality pada guru Pesantren Darul Arafah, artinya semakin tinggi kepemimpinan transformasional, maka semakin tinggi service quality, dan sebaliknya jika semakin rendah kepemimpinan transformasional, maka semakin rendah service quality pada guru Pesantren Darul Arafah. Hasil penelitian ini menunjukkan bahwa sumbangan yang diberikan variabel kepemimpinan transformasional terhadap variabel service quality adalah sebesar 28,3 persen, selebihnya 71,7 persen dipengaruhi oleh faktor lain yang tidak diteliti, seperti kepuasan kerja, employee empowermesnt, motivasi kerja, Organizational Citizenship Behavior (OCB), disiplin kerja, brand image, pelatihan keterampilan service quality, kompensasi dan gaya kepemimpinan serta remunerasi.

\section{Daftar Rujukan}

Akbaba, A. "Measuring Service quality in The Hotel Industry: A Study in A Business Hotel in Turkey". Hospitality Management 25, (online), hal $170 \quad-\quad 192,2006$, 
Tria Sari, Winida Marpaung, Diny Atrizka

Psyche 165 Journal Vol 13 No 1 (2020) 132-139

(http://www.sciencedirect.com/science/article/pii/S0278431905000940 atau DOI:10.1016/j.ijhm.2005.08.006, diakses 20 Juni 2017).

Ancok, D. Psikologi Kepemimpinan dan Inovasi. Jakarta: Erlangga, 2012.

Arifin, M. Kapita Selekta Pendidikan (Islam dan Umum). Jakarta: Bumi Aksara, 1995.

Azwar, S. Penyusunan Skala Psikologi. Yogyakarta: Pustaka Belajar, 2006.

Notoatmodjo, S. Pendidikan dan Perilaku Kesehatan. Jakarta: Rineka Cipta, 2003.

He, Q. C., An, Q., \& Lin, P. X. "Transformational Leadership, Psychological Capital and Front-line Sales Staffs' Service quality: Psychological Capital as a Mediator”. International Journal of $u$ - and e-Service, Science and Technology, (online), Volume 24, No. 7 pp.309-316, 2016, (http://jab.sagepub.com/content/35/3/373 atau http://dx.doi.org/10.14257/ijunesst.2016.9.7.31 diakses 20 Januari 2018).

Ismail, A., Halim, F. A., Abdullah, D. N. M. A., Shminan, A. S., Muda, A. L. A., \& Samsudin, S. "The Mediating Effect of Empowerment in the Relationship between Transformational Leadership and Service quality”. International Journal of Business and Management, (online), Vol. 4, No. 4, April 2009, (https://pdfs.semanticscholar.org/a0bc/67495824b62ec0fff24f7830dfa6c41ddd20.pdf, diakses 20 Juni 2018).

Meyer, J. P., \& Allen, N. J. Commitment in The Workplace: Theory, Research, and Application. USA: Library of Congress Cataloging-in-Publication Data, 1997, (http://sk.sagepub.com/books/commitment-in-the-workplace diakses pada 30 April 2018)

Mondy, R. Manajemen Sumber Daya Manusia Edisi Sepuluh. Jakarta: Erlangga, 2009.

Northouse, P.G. Leadership: Theory and Practice. London: SAGE Publications, 2007.

Northouse, P. G. Kepemimpinan Teori dan Praktik Edisi Ke-enam. Jakarta: indeks 2013.

Parasuraman, A,V. 2001. Delivering Quality Service. Terjemahan oleh Sutanto. New York: The Free Press.

Peraturan Pemerintah Republik Indonesia Nomor 19. 2005. Standar Pendidikan Nasional, (https://kemenag.go.id/file/dokumen/PP1905.pdf, diakses pada 11 Oktober 2018)

Putra, B. A. P. D. "Pengaruh Transformational Leadership Terhadap Financial Performance Melalui Service quality Sebagai Variabel intervening Pada Perusahaan Perbankan Di Surabaya". Business Accounting Review, (online), Vol. 4, No.1, Januari 2016 (85-96), (http://www.econjournals.com/index.php/ijefi/article/view/cdff1397, diakses 20 Januari 2018)

Tjiptono, F. Service Management: Mewujudkan Layanan Prima Edisi II. Yogyakarta: Andi, 2005.

Wibowo. Perilaku Dalam Organisasi. Jakarta: Rajawali Pers, 2013.

Wutun, R.P. Pengembangan Kualitas SDM dari Perspektif PIO. Jakarta: Bagian Psikologi Industri dan Organisasi Fakultas Psikologi Universitas Indonesia, 2001. 